\title{
Distribution and habitat associations of the critically endangered bird species of São Tomé Island (Gulf of Guinea)
}

\author{
RICARDO F. DE LIMA, HUGO SAMPAIO, JONATHON C. DUNN, \\ GABRIEL CABINDA, RICARDO FONSECA, GABRIEL OQUIONGO, \\ JOEL OQUIONGO, SEDNEY SAMBA, ARISTIDES SANTANA, \\ ESTEVÃO SOARES, LEONEL VIEGAS, ALICE WARD-FRANCIS, \\ LUÍS T. COSTA, JORGE M. PALMEIRIM and GRAEME M. BUCHANAN
}

\section{Summary}

São Tomé holds 20 endemic bird species, including the little known and 'Critically Endangered' Dwarf Olive Ibis Bostrychia bocagei, São Tomé Fiscal Lanius newtoni and São Tomé Grosbeak Neospiza concolor. We conducted a systematic survey of the core forest area, performing 1,680 point counts and compiling occasional observations, which enabled the identification of new areas of occurrence for the target species. MaxEnt distribution modelling suggested that the ibis and fiscal have roughly half of the potential area of occurrence that had been assumed ( 127 and $117 \mathrm{~km}^{2}$, respectively), while it more than doubled that of the grosbeak $\left(187 \mathrm{~km}^{2}\right)$. The south-west central region of the island, most of which is included in the São Tomé Obô Natural Park, has the highest potential for the Critically Endangered birds. We confirmed the association of all target species with native forest. The ibis preferred high tree density, while the fiscal selected low tree density and intermediate altitudes. Despite very restricted ranges, population sizes seem to be larger than previously assumed. These results suggest that the fiscal and grosbeak might be better classified as 'Endangered', while the ibis should maintain its status under different criteria, due to a very restricted range during the breeding season. This work provides vital ecological knowledge to support conservation action focusing on these species and their habitats, highlighting the need to improve the effectiveness of the São Tomé Obô Natural Park in protecting its unique biodiversity.

\section{Sumário}

São Tomé alberga 20 espécies endémicas de aves, incluindo a Galinhola Bostrychia bocagei, o Picanço Lanius newtoni e o Anjoló Neospiza concolor, todos pouco conhecidos e em perigo crítico. Prospectámos sistematicamente o bloco central de floresta, realizando 1680 pontos de contagem e compilando observações ocasionais, que permitiram identificar novas áreas de ocorrência para as espécies alvo. A modelação de distribuição usando MaxEnt sugere que a galinhola e o picanço têm aproximadamente metade da área potencial de ocorrência que havia sido assumida (127 e $117 \mathrm{~km}^{2}$, respectivamente), enquanto que mais que duplicou a do anjoló $\left(187 \mathrm{~km}^{2}\right)$. A região centro e sudoeste da ilha, maioritariamente incluída no Parque Natural do Obô de São Tomé, tem o potencial mais elevado para as aves criticamente ameaçadas. Confirmámos a associação de todas as espécies alvo com a floresta nativa. A galinhola prefere densidades arbóreas elevadas, enquanto que o picanço selecciona densidades arbóreas baixas e altitudes intermédias. Apesar das distribuições muito restritas, os tamanhos populacionais aparentam ser maiores do que assumido anteriormente. Estes resultados sugerem que o picanço e o anjoló poderão ser melhor classificados como em perigo, enquanto que a galinhola deverá manter o 
seu estatuto, sob critérios distintos, devido à distribuição muito restrita durante a época reprodutora. Este trabalho esclarece alguns aspectos ecológicos cruciais para fundamentar acções de conservação focadas nestas espécies e nos seus habitats, sublinhando a necessidade de melhorar a eficácia do Parque Natural do Obô de São Tomé para proteger a sua biodiversidade única.

\section{Introduction}

The island of São Tomé (Gulf of Guinea, Central Africa) is an important centre of endemism (Jones 1994). The number of endemic birds it holds is particularly remarkable for a small island (Stattersfield et al. 1998, Kier et al. 2009, Buchanan et al. 2011, Le Saout et al. 2013). It has 50 resident bird species, of which 17 are single-island endemic species, three are Gulf of Guinea endemic species and eight are endemic subspecies, ranging across eight orders and 19 families (Jones and Tye 2006, Melo 2007). The island is also unusual among oceanic islands with isolated and unique avifaunas in that there are no recorded anthropogenic extinctions of birds (Jones and Tye 2006).

The endemic avifauna of São Tomé is clearly associated with the persistence of the island's forest-dominated landscape (de Lima et al. 2013a). Preserving the remaining native forests and restoring degraded habitat are top conservation priorities, namely within and around the island's only protected area, the São Tomé Obô Natural Park (ONP), where most of the endemic species are found (de Lima 2012, Ndang'ang'a et al. 2014). These forests are under high level anthropogenic pressure (Salgueiro and Carvalho 2007). Threats such as land-use intensification, overexploitation and invasive species are likely to continue to have a strong impact on forest ecosystems and on the endemics in the nearby future (Jones et al. 1991).

Nine of São Tomé's endemic bird species are currently classified as threatened, including three which are 'Critically Endangered'; the Dwarf Olive Ibis Bostrychia bocagei, São Tomé Fiscal Lanius newtoni and São Tomé Grosbeak Neospiza concolor (IUCN 2013, Ndang'ang'a et al. 2014). The ibis is a lowland species found in old-growth or mature secondary rainforest in the south and centre of the island, and it breeds from September to February (Jones and Tye 2006, Maia et al. 2014, Azevedo 2015, Margarido 2015). The fiscal is known only from well-preserved forest, with low understorey density and in areas of high rainfall (Jones and Tye 2006), occurring from the lowlands up to 1,395 $\mathrm{m}$ above sea level (Maia and Alberto 2009). The grosbeak was thought to be a lowland old-growth forest specialist, but recent observations in secondary forest at 1,400 m suggest that it might be more widespread than previously thought (Solé et al. 2012).

The implementation of effective conservation measures, requires basic ecological knowledge, which is currently lacking. A better knowledge of distribution and habitat associations is needed in order to identify target areas for intervention and protection, monitor population trends, manage the habitat and tackle threats. Here we describe an intensive survey of this island's core forest ecosystems that, together with ad hoc observations, has been used to produce maps of potential species distribution and to identify the areas of the island which are most important for all three species, applying reserve selection algorithms. We also describe broad habitat associations for the species. Finally we assess the implications of this new information for reviewing the conservation status of the species and to guide conservation activities.

\section{Methods}

\section{Study area}

São Tomé $\left(857 \mathrm{~km}^{2}\right)$ is located just north of the Equator, $255 \mathrm{~km}$ west of continental Africa and belongs to the small island nation of São Tomé and Príncipe. The island is rugged, especially in the centre and south-west, with several peaks above 1,50o m and the highest peak, Pico de São Tomé, at $2,024 \mathrm{~m}$. The mountainous topography creates strong climatic gradients, with the annual rainfall ranging from less than $600 \mathrm{~mm}$ in the north-east to more than $7,000 \mathrm{~mm}$ in the south-west, 
and the mean annual temperatures ranging from around $30^{\circ} \mathrm{C}$ at sea level to $18^{\circ}$ at higher altitudes. Humidity and cloud cover are high throughout the year for most of the island, but there is a wellmarked seasonality. The main dry season, locally known as gravana, extends from mid-May to early September and is characterised by low rainfall and lower temperatures. The rainy season extends through the rest of the year, with a small dry season, the gravanito, occurring between December and February (Silva 1958, Tenreiro 1961).

The native forest can be separated in four main types, differentiated by climatic conditions and plant species composition; mangrove, lowland, montane and mist (Monod 1960). The mangrove is restricted to small coastal areas. Lowland forest goes from sea level up to $800 \mathrm{~m}$ and is characterised by a sparse understorey, and a high and dense canopy. Montane forest spans 800-1400 $\mathrm{m}$ and has a high tree density and species richness, with medium understorey and epiphyte density. Mist forest occupies the summit of the island and is typically much lower, with sparse tree cover and very high epiphyte densities.

The island was first described as being entirely covered by dense tropical forest, but since then, humans have extensively changed its ecosystems (Eyzaguirre 1986). At least 10\% of the island is now covered by non-forest land-use types, such as oil palm monoculture, horticulture and open savanna. The remaining area is covered by similar extents (c.30 \%) of shade plantation, secondary forest and native forest (Salgueiro and Carvalho 2007). Native forest persists only in mountainous portions of the island, where human presence remains scarce. Most of these best preserved forests are now classified as ONP (DGA 2006). The park extends through most of the centre and southwest of the island, covering nearly one third of it, but enforcement is weak and protection is not very effective (de Lima et al. 2013b).

This study focuses on the three Critically Endangered bird species endemic to São Tomé; the Dwarf Olive Ibis, the São Tomé Fiscal and the São Tomé Grosbeak. The ibis is presumed to occupy an area of $213 \mathrm{~km}^{2}$, with a declining population of $70-400$ individuals (IUCN 2013). It is a lowland species found in old-growth or mature secondary rainforest in the south of the island. It is usually found feeding on the ground and it breeds from September to February (Jones and Tye 2006, Maia et al. 2014, Azevedo 2015, Margarido 2015). It is threatened by habitat loss and degradation, hunting and human disturbance, with climate change and predation by exotic species being considered as potential serious threats (Ndang'ang'a et al. 2014).

The fiscal is thought to occupy $260 \mathrm{~km}^{2}$ and, as a precautionary measure, it is assumed to have a population smaller than 50 adult individuals (IUCN 2013). It is known only from well-preserved forest, with low understorey density and in areas of high rainfall (Jones and Tye 2006). It has been found from the lowlands up to 1,395 m (Maia and Alberto 2009, Lewis 2015). It is usually heard in the distance or found perching on low-lying branches, from where it flies to hunt small invertebrates (Jones and Tye 2006, Lewis 2015). There are some indications that it breeds from November to February. Habitat degradation by exotic plant species is considered a potential threat (Ndang'ang'a 2014).

The grosbeak is presumed to occur in an area of $88 \mathrm{~km}^{2}$ and, as a precautionary measure, it is assumed to have a population smaller than 50 adult individuals (IUCN 2013). Thought to be a lowland old-growth forest specialist, restricted to the south of the island, the species was recently found using an area of secondary forest in the central mountain range, at an altitude of $1,400 \mathrm{~m}$ It has also been found feeding on fruits of relatively abundant and widespread species, some of which are typical of disturbed areas. These new observations suggest that the scarcity of records for this species might be linked to its shy behaviour, and that it might be more abundant and widespread than previously thought (Solé et al. 2012). Habitat degradation due to human disturbance and spread of exotic species have been identified as the major threats to the survival of this species (Ndang'ang'a et al. 2014).

\section{Survey design}

We gathered occasional and systematic observations of the Critically Endangered bird species of São Tomé. Occasional observations included our own sporadic records and those collected by 
other ornithological researchers over the last 15 years. We contacted those authors and compiled all available information in a database with a GIS component, based on locations recorded on GPS.

Systematic surveys of São Tomé's main forest block took place between 2013 and 2015. The study area was divided into 99 square tetrads of $4 \mathrm{~km}^{2}$ (Figure 1 ). We surveyed a randomly selected quarter of each tetrad throughout the study area and more intensively in some areas, such as the south-east (de Lima et al. 2013 b). In each $1-\mathrm{km}^{2}$ quarter we undertook five 10-minute point counts, separated by at least $200 \mathrm{~m}$. When feasible, point counts were scattered across the $1-\mathrm{km}^{2}$ quarter so as to represent environmental variability roughly in proportion to its availability (e.g. habitat type, altitudinal gradient, and distance to rivers and roads). The number of individuals of each Critically Endangered bird species detected during each point count was recorded. The location and altitude of each point were registered using a GPS. Habitat at each point was assessed in terms of broad land-use type, slope, number of trees and understorey density (Table 1 ). To assess seasonality, sampling took place during the main dry season (gravana) of 2013 and 2014, and during the gravanito of 2014 and 2015, which corresponds to a small dry season at the end of the breeding season for most bird species in São Tomé (Jones and Tye 2006).

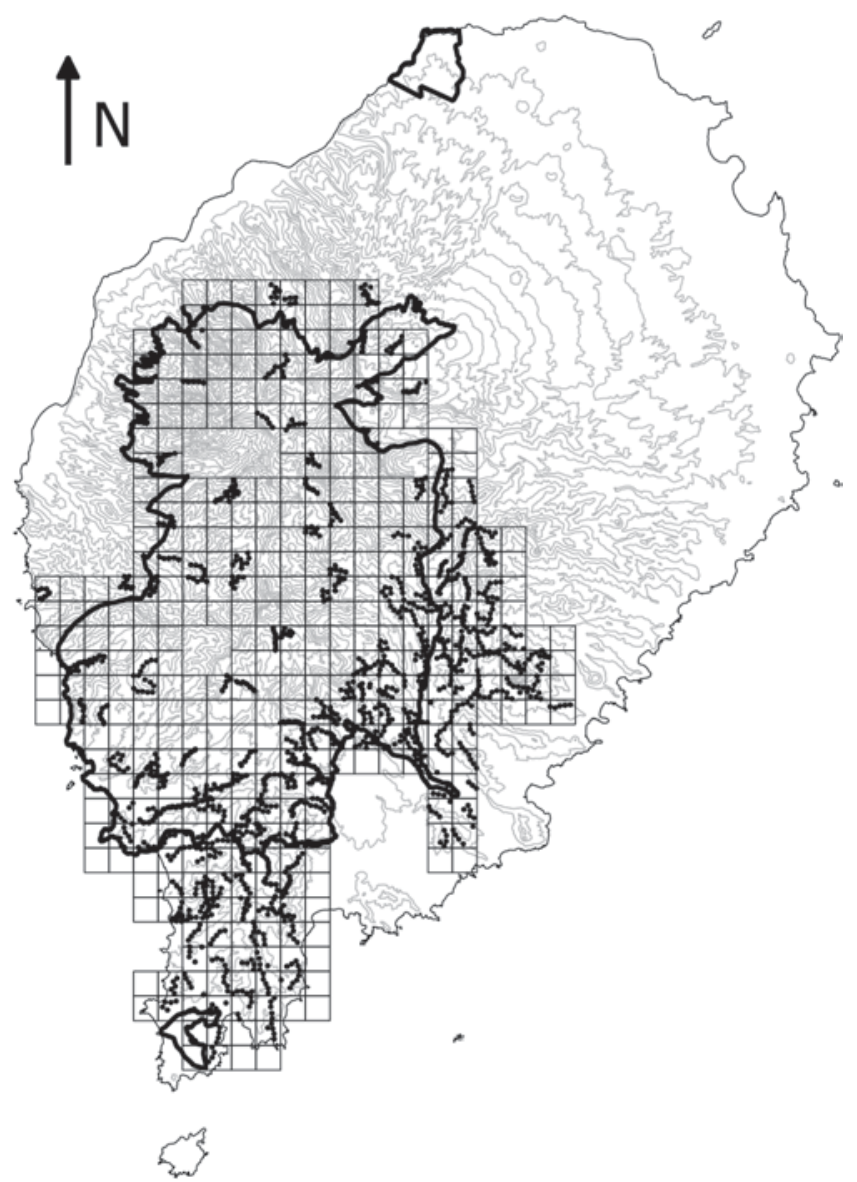

Figure 1. Map of São Tomé Island showing study area. The squares represent $1-\mathrm{km}^{2}$ quadrats in the $4-\mathrm{km}^{2}$ tetrads that were sampled at least once. The dots indicate systematic point counts. The boundaries of the São Tomé Obô Natural Park are shown by the bold black lines. The 10o-m contour lines are shown in grey and island outline in black. 
Table 1. Point count habitat variables. Each variable was assessed within a 20-m radius around each point count.

\begin{tabular}{ll}
\hline Variable & Description \\
\hline Habitat type & Native forest, secondary forest or plantation \\
Slope & 1 - none or very soft; 2 - soft; 3 - medium; 4 -steep; 5 - very steep \\
Number of trees & Count of all trees with diameter at breast height larger than $30 \mathrm{~cm}$ \\
Understorey density & 1 -none or very sparse; 2 - sparse; 3 - medium; 4 - dense; 5 - very dense \\
\hline
\end{tabular}

\section{Species distribution models}

Species distribution models (SDMs) were created using MaxEnt in the "dismo" R package (Hijmans et al. 2015, R Development Core Team 2015). MaxEnt is a machine learning method that produces niche models from environmental data, and has been found to perform well in comparison to other SDM methods (Elith and Graham 2009).

We created an SDM for the annual gravana (long dry season) and gravanito (short dry season) distribution of each species. Given that the exact dates for the seasons can vary, the gravana was truncated to June, July and August, and the gravanito to January and February. We identified 33 potential predictor variables for inclusion in the SDMs: 19 bioclimate layers (Hijmans and Cameron 2005; www.worldclim.org/bioclim), 12 normalised difference vegetation index (NDVI) layers (Spotvegetation sensor through VITO; www.spot-vegetation.com), elevation (Jarvis et al. 2008) and slope (created from the elevation layer). The NDVI layers for a 13-year period (1999-2012) were combined to create a set of monthly averages, and used as a continuous summary of land cover. All predictor variables were standardised to a $1-\mathrm{km}^{2}$ spatial scale and processed using ArcMap version 10.2. We created a set of uncorrelated predictor variables and a set of predictor variables that had the greatest average percentage contribution to the maximal model (Table $\mathrm{S}_{1}$ in the online supplementary material). For the seasonal models, only the corresponding NDVI layers were retained.

The SDMs were built using the systematic surveys as training data and tested using the occasional observations (Table S2), except for the grosbeak in the gravana. In this case, because there were too few systematic observations, both sets of observations were combined as training data and the resulting model was not tested. We used 886 pseudo-absences in MaxEnt, the number of non-duplicated training records, unique records for each $1-\mathrm{km}^{2}$ raster cell. The optimal feature function combination was identified based on the number of unique sample points (Phillips and Dudík 2008), the "ENMeval" R package (Muscarella et al. 2014, R Development Core Team 2015) was used to run a series of models with varying regularisation values (from 0.5 to 5 at intervals of 0.5), and the final model was chosen based on AICc (Warren and Seifert 2011).

The final models were created with a raw output for calculating the model AICc. Ten cross validations were undertaken to generate folds of randomly selected presence data, allowing us to run each model 10 times, exclude each fold in turn and use the fold to validate the data (Phillips and Dudík 2008). This enabled us to assess whether the response curves were smooth and biologically sensible. To aid interpretation, these models were repeated with a logistic output, being partitioned using the mean equal training sensitivity and specificity threshold values to identify the minimum area of land required for each species. This threshold was chosen because it minimises the rate of false positives and negatives. We calculated the spatial overlap between the SDM of each species for the predicted annual, gravana and gravanito distribution, using the "calc.niche.overlap" function of the "ENMeval" R package (Schoener's D and Warren's I statistics; R Development Core Team 2015) and Map Comparison Kit 3.2.3. (Cohen's Kappa statistic; Visser and De Nijs 2006).

\section{Spatial conservation planning}

We used the spatial conservation planning software 'Zonation' to identify important areas for the study species in the three periods considered and giving equal weight to each species. This software produces a hierarchical prioritisation based on the conservation value of sites (Moilanen et al. 2005, 
Moilanen 2007) using a complementarity-based algorithm that iteratively removes the cells whose loss causes the smallest decrease in conservation value in the remaining network. The resulting hierarchy of nested outputs corresponds to different degrees of conservation value within the landscape and may be used as a guide to determine the level of protection needed. It differs from previous target based planning or maximum coverage approaches that provide a single optimal output (Moilanen 2007). One grid cell was removed in each iteration step (warp factor). The spatial overlap between the three Zonation outputs was calculated using the "calc.niche.overlap" function from the "ENMeval" R package (Schoener's D and Warren's I statistics; R Development Core Team 2015).

\section{Habitat associations}

We used generalised linear models (Bolker et al. 2009, Zuur et al. 2009, R Development Core Team 2015) to assess the influence of environmental variables (altitude, slope, number of trees, understorey density, habitat type and season) on the presence of each species. There were 607 point count locations from the gravanito and 316 point count locations from the gravana, for which we had a complete characterisation of all environmental variables. Since there was a high prevalence of absences of Critically Endangered birds during the point counts, presences were modelled against data from an equal number of randomly selected point counts during which each species had not been recorded. To identify which variables had the greatest support for explaining the presence of the Critically Endangered birds, we used model averaging and relative variable importance based on second-order Akaike information criterion (AICc) automated model selection (Burnham and Anderson 2002, Barlow et al. 2010), from the "MuMIn" R package (Barton 2013, R Development Core Team 2015).

\section{Results}

We sampled 720 point counts during the gravanito and 96o during the gravana. In total we recorded 33,137 birds, belonging to 39 species, including the 20 endemic species and all endemic subspecies, except Harlequin Quail Coturnix delegorguei histrionica and Barn Owl Tyto alba thomensis. We detected 38 ibises in 21 point counts, III fiscals in 86 point counts and 22 grosbeaks in 16 point counts. The larger sampling effort during the gravana was not reflected in the number of records for the Critically Endangered birds, with just 18 ibises in 8 points, 46 fiscals in 35 points and three grosbeaks in three points from this season. We present these figures to indicate broad encounter rates, since we cannot rule out the possibility of counting the same individual on proximal squares or subsequent seasons.

\section{Distribution}

We obtained records of new areas of occurrence for all three of the target species. The ibis was registered along the Lembá, Ana Chaves and Iô Grande river valleys, and in the proximity of Maria Fernandes Peak, outside the ONP. The fiscal seems to occur mostly at mid-altitudes south of Pico de São Tomé and around Cabumbé Peak. The distribution of the grosbeak was greatly expanded, with records from Morro de Dentro, Ana Chaves Peak, the Lembá river valley and the southeast slopes of Cabumbé Peak (Figure S2).

The SDMs scored generally high in the AUC test, ranging from $0.80 \pm 0.10 \mathrm{SD}$ to $0.95 \pm 0.07 \mathrm{SD}$ (Table $\mathrm{S}_{3}$ ). The models using all significant predictors always performed better than those using the uncorrelated set of predictors, except for the fiscal in the gravana. The variables that best predicted the presence of the three target species for the annual models were those related to: elevation; NDVI, especially in June; and precipitation, namely during the wettest and warmest months (Table $\mathrm{S}_{4}$ ). The variables related to precipitation were consistently chosen as predictors for the presence of the bird species across the seasons, most notably for the ibis. 
The logistic outputs from the SDMs were turned into binary outputs of potentially occupied and unoccupied $1-\mathrm{km}^{2}$ cells, based on the equal training selectivity and specificity thresholds. The resulting maps (Figure. $2 \mathrm{a}, 2 \mathrm{~b}$ and $2 \mathrm{c}$ ) indicated that, across the whole year, the potential area of occurrence was $127 \mathrm{~km}^{2}$ for the ibis, $117 \mathrm{~km}^{2}$ for the fiscal and $174 \mathrm{~km}^{2}$ for the grosbeak. During the gravana these areas expand to over $165 \mathrm{~km}^{2}$ for the ibis, $197 \mathrm{~km}^{2}$ for the fiscal and $190 \mathrm{~km}^{2}$ for the grosbeak, while in the gravanito they change to 65,113 and $201 \mathrm{~km}^{2}$, respectively (Figure $\mathrm{S}_{1}$ ). There is a
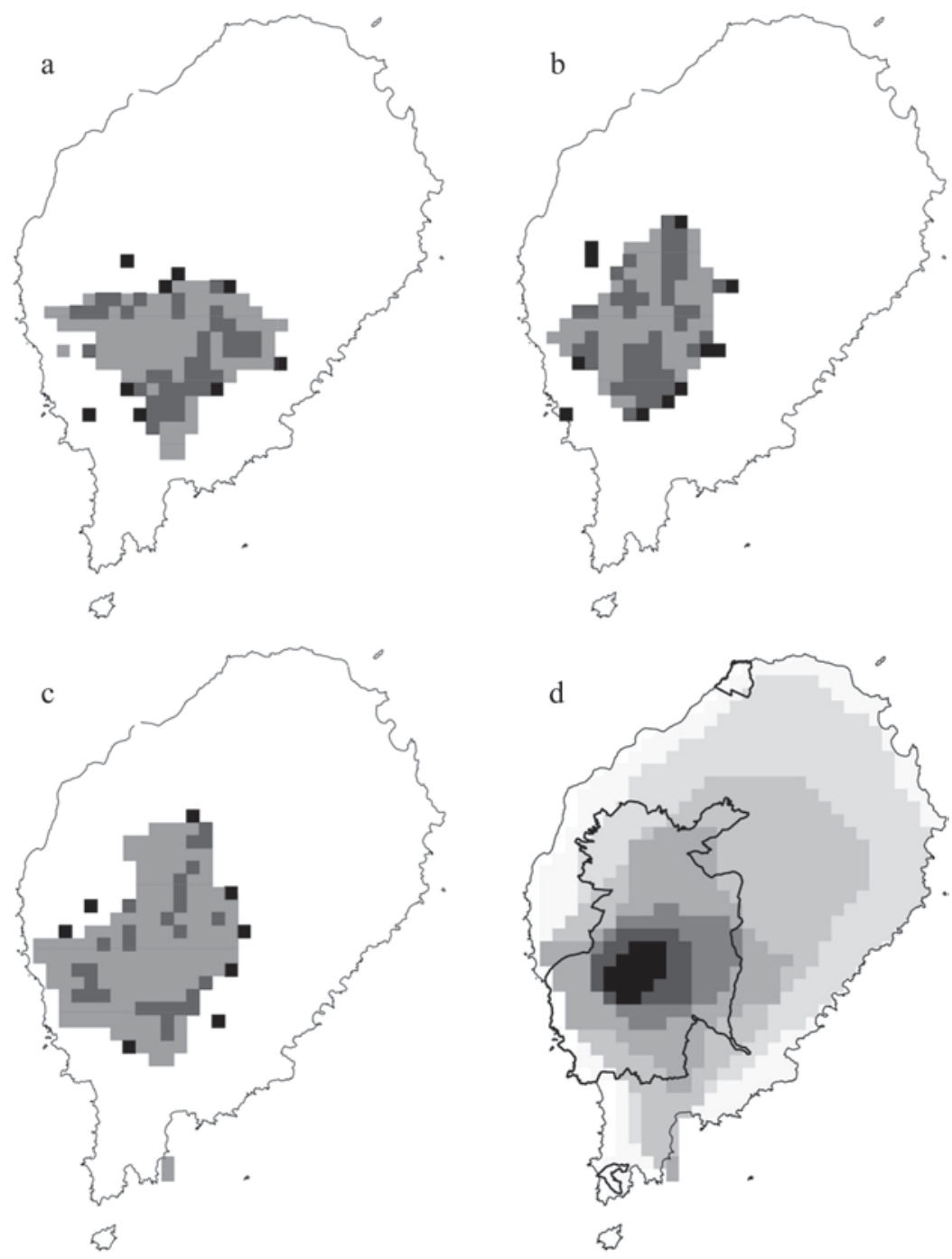

Figure 2. The distribution of São Tomé Dwarf Olive Ibis (a), Fiscal (b) and Grosbeak (c). The black quadrats represent confirmed locations, while the superimposed grey areas represent suitable ranges, according to the categorical annual distribution predicted by logistic MaxEnt modelling. Zonation based on categorical SDM (d) is also shown, with the darkest colours indicating the most important conservation areas and the coolest colours indicating the least important conservation areas $(\mathrm{o}-19 \%=$ almost white, $20-49 \%=$ very light grey, $50-74 \%=$ light grey, $75-89 \%=$ intermediate grey, $90-94 \%=$ dark grey, $95-97 \%=$ very dark grey and $98-100 \%=$ black). 
strong spatial overlap in the seasonal distribution of each species, with the ibis exhibiting the most accentuated seasonal changes in distribution (Table 2, Figure $\mathrm{S}_{1}$ ).

The south-west central region of São Tomé has high potential for the occurrence of the three Critically Endangered birds, and was thus identified as the most important area of the island in the output of the zonation analysis (Figure $2 \mathrm{~d}$ ). This key area for conservation is largely coincident with the ONP: $99.1 \%$ for the top 10\% threshold, and $82.7 \%$ for the top $25 \%$ threshold.

\section{Habitat associations}

We recorded the ibis in 13 point counts with complete habitat characterisation, the fiscal in 75 and the grosbeak in 12. Comparing the habitat characteristics of these locations with that of an equal number of unoccupied locations, indicated that the three species showed a preference for native forest. Additionally, the Dwarf Olive Ibis selected areas with higher number of trees and was detected mostly during the gravanito, while the fiscal preferred a lower number of trees and intermediate altitudes (Table 3 , Figures 3 and $\mathrm{S}_{3}$ ).

The ibis was mostly found in lowlands, but we obtained 12 records above $600 \mathrm{~m}$ (five during point counts, plus seven occasional records), from the Lembá and Ana Chaves river basins. These include three records above $900 \mathrm{~m}$, south of Ana Chaves Peak, one of which refers to two juvenile individuals found near a nest at $935 \mathrm{~m}$ (Figure $\mathrm{S}_{2}$ ). We have also detected it in secondary forest: twice during the systematic point counts (out of 21 points with confirmed presence) and 16 times from the occasional records (out of 114 records). The fiscal occurs only in native forest, preferring areas between 400 and $1,300 \mathrm{~m}$ even though its altitudinal range can extend from 185 to $1,504 \mathrm{~m}$. The presence of the grosbeak in montane forest was confirmed several times at distinct locations: Ana Chaves Peak (929, 951 and 1,258 m), Morro Provaz (1,231 m), Morro de Dentro (1,309 m) and Lagoa Amélia (1,397 m; Figure S2). A significant number of records considering that higher altitude forests cover only $85 \mathrm{~km}^{2}$ of São Tomé and that four out of 16 point counts with grosbeak were at altitude ( $25 \%)$, while only 170 out of the 1,680 point counts were at altitude (10\%). We also detected the grosbeak in secondary forest: twice during the systematic point counts (out of 16 points with confirmed presence) and thrice from the occasional records (out of 23 records).

\section{Discussion}

The comprehensive survey of São Tomé forests has allowed, together with information gathered from other researchers, a significant improvement on our knowledge about the distribution, ecology and conservation status of the São Tomé Dwarf Olive Ibis, Fiscal and Grosbeak.

Table 2. Spatial overlap between categorical MaxEnt SDM outputs. The lines show the values for each of the three Critically Endangered bird species and across all species. Each column shows the values for each possible comparison between the three seasonal models considered (annual, gravana and gravanito). Values correspond to Schoener's D, Warren's I and Cohen's K statistics, respectively. For across the species, only D and I statistics values are shown. For D and I statistics, o means no overlap and I complete overlap. For K o means no agreement, values between o and 0.20 slight agreement, between 0.21 and 0.40 fair agreement, between 0.41 and 0.60 moderate agreement, between 0.61 and 0.80 substantial agreement and between 0.81 and $I$ almost perfect agreement.

\begin{tabular}{llll}
\hline Species & Annual/Gravana & Annual/Gravanito & Gravana/Gravanito \\
\hline Ibis & $0.54 / 0.61 / 0.91$ & $0.48 / 0.67 / 0.95$ & $0.22 / 0.35 / 0.89$ \\
Fiscal & $0.48 / 0.62 / 0.90$ & $0.72 / 0.73 / 0.95$ & $0.44 / 0.58 / 0.89$ \\
Grosbeak & $0.47 / 0.49 / 0.85$ & $0.53 / 0.56 / 0.87$ & $0.66 / 0.68 / 0.90$ \\
All species & $0.84 / 0.96$ & $0.91 / 0.98$ & $0.87 / 0.97$ \\
\hline
\end{tabular}


Table 3. Relative importance (Imp.) and averaged coefficients (Coef.) of variables obtained from generalised linear models on the presence of São Tomé's Critically Endangered bird species. The grey shading highlights variables with the highest relative importance values (larger than o.3) and the asterisks indicate variables that on their own perform better than the null model. A relative importance value of 1 means that the variable is included in all best models (Figure $\mathrm{S}_{3}$ ). Habitat and Season are factorial variables with positive values corresponding to a preference for secondary forest and gravanito, respectively.

\begin{tabular}{|c|c|c|c|c|c|c|}
\hline & \multicolumn{2}{|l|}{ Ibis } & \multicolumn{2}{|l|}{ Fiscal } & \multicolumn{2}{|c|}{ Grosbeak } \\
\hline & Imp. & Coef. & Imp. & Coef. & Imp. & Coef. \\
\hline Altitude & 0.236 & 0.001 & $0.322^{*}$ & -0.001 & 0.207 & 0.000 \\
\hline Habitat & $0.430^{*}$ & -1.770 & $1.000^{*}$ & -20.668 & $0.650^{*}$ & -2.171 \\
\hline Number of trees & $0.435^{*}$ & 0.197 & 0.372 & -0.071 & 0.269 & -0.128 \\
\hline Slope & 0.287 & -0.330 & 0.260 & -0.030 & 0.204 & 0.072 \\
\hline Understorey Density & 0.238 & 0.292 & 0.260 & 0.008 & 0.242 & -0.273 \\
\hline Season & 0.412 & 1.399 & 0.297 & -0.297 & 0.227 & 0.633 \\
\hline
\end{tabular}

\section{Distribution}

We have greatly increased the number of confirmed locations for all of São Tomé's Critically Endangered bird species, and gained a better understanding of the distribution of their potential habitats. We found that the potential distribution of both the ibis and the fiscal are much more
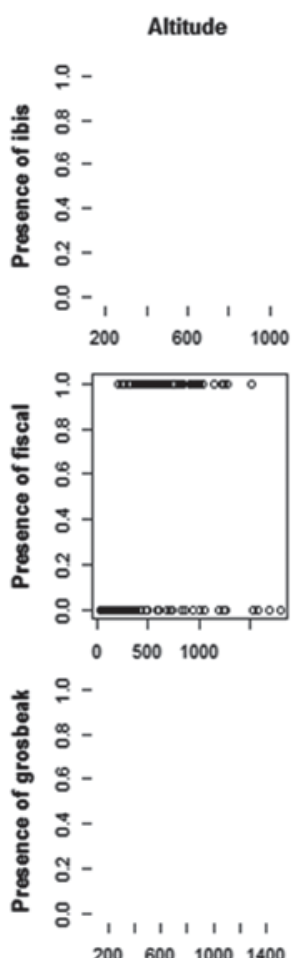
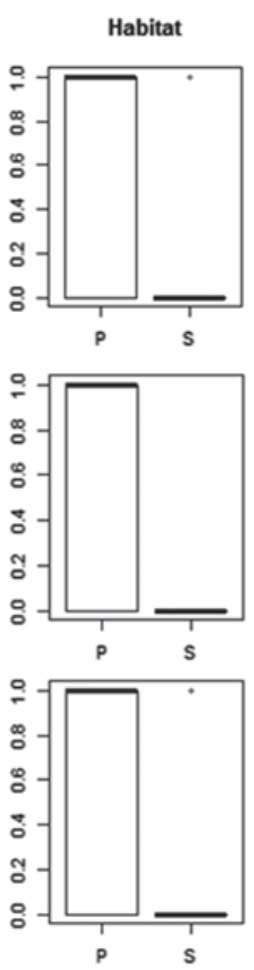

Number of trees
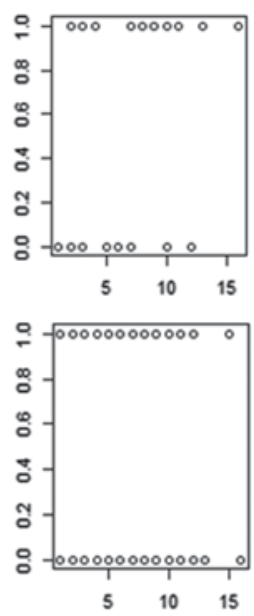

$\stackrel{\circ}{-}-$

$\stackrel{\infty}{\circ}-$

:-

: -

긍 -

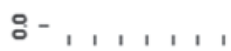

246812
2012

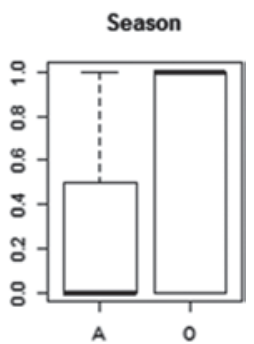

으-

品 -

응-

후 -

긍 -

응 -

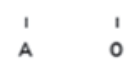

으-

$\stackrel{\infty}{\circ}-$

: -

: -

공 -

응 -

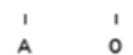

Figure 3. Relationship between the presence of São Tomé's Critically Endangered bird species and environmental variables. Only the variables with the highest relative importance values for each species are plotted (Table 3). 
restricted than previously assumed, having changed from 213 to $127 \mathrm{~km}^{2}$ and from 260 to $117 \mathrm{~km}^{2}$, respectively. The grosbeak, on the other hand, seems to be more widespread, with surveys having extended its potential range from 88 to $187 \mathrm{~km}^{2}$. The ibis also seems to have strong seasonal changes in distribution, being restricted to just $65 \mathrm{~km}^{2}$ during its breeding season in the gravanito.

All target species are strongly restricted to the south of the island, and notably to the south-west. The ONP covers most of the areas with high potential for the three species, but leaves out $38 \mathrm{~km}^{2}(82.7 \%)$ of the top $25 \%$ priority areas (Figure $2 \mathrm{~d}$ ). These include around $20 \mathrm{~km}^{2}$ between the Iô Grande river and Maria Fernandes Peak to the east of ONP, and smaller areas next to Juliana de Sousa (west), Caué river and Monte Carmo (south border), and Calvário and Nova Ceilão (north-east; Figure $\mathrm{S}_{2}$ ). The ONP is well located for the protection of São Tomé's Critically Endangered bird species, especially considering that it aims to protect many other biodiversity components.

\section{Habitat associations}

We confirmed that the three target species are strongly linked to the occurrence of native forest. In addition, the ibis is associated with areas with a higher number of trees, and the fiscal with areas with a lower number of trees at intermediate altitudes.

The ibis seems to have a preference for dense forests, in flat areas and with large trees (Margarido 2015). However, the species is not restricted to lowland, as we have found it at $950 \mathrm{~m}$. The fiscal occurs only in native forest, preferring areas with less trees at mid-elevation. This confirms that the fiscal is not a lowland species, and further suggests that it is associated with more open areas within the closed-canopy forest (Lewis 2015). These habitat associations make sense in light of the more open habitats used by other shrike species (Yosef 2008). In locations with these specific characteristics the fiscal can be fairly abundant, but it is hard to estimate population sizes, since large extents of area predicted as suitable for its occurrence are extremely difficult to access (Lewis 2015). The occurrence of the grosbeak at higher altitudes was confirmed in new locations, as was its occasional appearance outside the ONP and in secondary habitats near native forest (Solé et al. 2012).

\section{Threats}

We confirmed that all target species are strongly linked with the occurrence of native forest, indicating that the protection of this forest is key to ensuring the long-term survival of three bird species. Habitat degradation has been listed as a key threat to their survival (Ndang'ang'a et al. 2014) and it seems to have a negative impact on all species: the fiscal is restricted to native forest, while the ibis and the grosbeak appear to occur at lower densities in secondary forests, but only if these are mature and in the vicinity of native forest.

The ibis's association with lowland forests in flat areas and with large trees makes it especially prone to human activities that also tend to occur in these areas, such as hunting, logging and deforestation. The apparent concentration of the ibis around the south-west of the ONP during the breeding season is particularly concerning, since this region is being targeted for development, including a recently implemented $30-\mathrm{km}^{2}$ oil palm monoculture and a proposed large hydroelectric dam (de Lima et al. 2013b, Azevedo 2015). Of São Tomé's Critically Endangered bird species, the ibis is also the only one targeted by hunters (Carvalho et al. 2015). Recent interviews revealed that subsistence hunters might be killing hundreds of ibises every year, clearly surpassing any previous estimates and making this a key threat to its survival (Sampaio et al. 2016).

The fiscal was the only species restricted to native forest. This might suggest it is the most sensitive to habitat degradation but, on the other hand, its preference for rugged inaccessible areas makes it less vulnerable to the direct impact of human activities.

Despite the many new records, the grosbeak remains the least seen and most mysterious of São Tomé endemic bird species. The significant change in the number of records between seasons 
(two birds detected during the gravana, against 18 during the gravanito) suggests that the scarcity of records might be due to its shyness and not necessarily due to a very low population size. Therefore, the grosbeak might be more widespread and numerous than previously thought (Jones and Tye 2006).

During fieldwork we detected several introduced animal species (e.g. mona monkey Cercopithecus mona, African civet Civettictis civetta, black rat Rattus rattus, black cobra Naja melanoleuca and feral pig Sus scrofa) in the vicinity of areas where the Critically Endangered birds occur. There is no solid evidence that these exotic species are having a negative impact on the birds, and the impact of non-native species on São Tomé's native biodiversity remains little studied as a whole (Dutton 1994, Ndang'ang'a et al. 2014). Nevertheless, introduced species are well known for having strong negative impacts on island species (Trevino et al. 2007), and the precautionary principle advises care until such fears are disproved. Many of these exotic animals are likely to prey on birds, others, like many of the invasive plants or the feral pig, might degrade the overall quality of habitat. The quinine plant Cinchona ledgeriana, for instance, might pose a serious threat to the fiscal, since it occupies the understorey (Diniz et al. 2002), which this bird needs to be open for hunting (Jones and Tye 2006, Lewis 2015).

\section{IUCN Red List conservation status}

The revised potential distributions presented here might necessitate a review of the species' IUCN Red List status. The ibis is currently classified as 'Critically Endangered' due to having a declining population, fewer than 250 mature individuals and being confined to a single location (criterion C2a(ii); IUCN 2001, 2013). The species is restricted to less than $100 \mathrm{~km}^{2}$ during the breeding season and to a single location, with an inferred continuing decline in the area, extent and quality of its habitat, and in the number of mature individuals, so it should retain its status, under different criteria (Bıa,b(iii,v)), even if its population is larger than previously assumed.

The fiscal and the grosbeak are both currently classified as Critically Endangered due to having extremely small population sizes, with fewer than 50 mature individuals (criterion D; IUCN 2001, 2013). Our observations, together with those of other authors (Solé et al. 2012, Ndang'ang'a et al. 2014, Lewis 2015), suggest that their population sizes may be higher. If this proves to be the case, the category of 'Endangered' will perhaps be more appropriate, due to their extents of occurrence being smaller than $5,000 \mathrm{~km}^{2}$ and restricted to a single location, with an inferred continuing decline in the number of mature individuals and in the area, extent and quality of their habitats (criterion Bıa,b(iii,v)).

\section{Priorities for future research}

Most of the areas where the native forest persists are difficult to access due to the very rugged terrain and very high annual rainfall. These natural conditions have guaranteed protection from human interference, but have also made it difficult to study their ecosystems and species. This study is part of the most intensive systematic biological survey of these remote areas, during which data on other taxa (e.g. terrestrial vertebrates, land snails and plants) was also collected, improving knowledge of their distribution, ecology and conservation status (e.g. de Lima et al. 2016). These surveys have collected extensive evidence of the importance of the native forest for maintaining many of the island's endemic species, but have also shown that each species relies on specific areas of the forest for its survival. For instance, while the ibis is associated with high tree density in the lowlands, the fiscal seems to prefer lower tree densities at intermediate altitudes. These specific habitat associations pose a challenge to conservation prioritisation and intervention, as they demand a differential treatment of ecosystems to ensure the persistence of multiple biodiversity components. It is therefore crucial to keep improving our understanding of the relationship between species and ecosystems.

All target species were found more often during the gravanito. This suggests that they become more abundant or easier to detect during this season, and further supports the hypothesis that it coincides with the breeding season for most bird species in São Tomé, as has been previously 
described (Jones and Tye 2006, Maia et al. 2014, Azevedo 2015, Margarido 2015). This finding also indicates that this is most likely the best time of year to census these species. Since resources for monitoring are likely to be scarce, we would prioritise having more robust data for a single season, than dispersing resources in multiple-season assessments, thus maximising detection by surveying when the species are easier to find. Estimating and monitoring population sizes, following specific censuses for each species should be a top research priority, to ensure a better sustained revision of the conservation statuses and provide bases for evidence-based management.

A key priority for further research is to gain a better understanding of the role of potential threats, such as the collection of forest products (timber, charcoal, quarry species, palm wine, medicinal plants) and introduced animal and plant species (de Lima et al. 2013a). Tackling the hunting of the Dwarf Olive Ibis is also a top priority, as it seems to be posing an immediate threat to the survival of this species and depends on complex socio-economic drivers (Carvalho et al. 2015, Sampaio et al. 2016). This is essential when considering the species' restricted breeding range, alongside the fact that hunting pressure may already be limiting the population density in the areas of suitable habitat we have identified.

\section{Implications for conservation}

We confirmed that all of São Tomé's Critically Endangered bird species have a very limited distribution, strongly associated with the occurrence of the best preserved patches of native forest. These are mostly located in the centre and south-west of the island and within the ONP (Salgueiro and Carvalho 2007), which despite its legal recognition is weakly enforced (de Lima et al. 2013b). Increasing the effectiveness of the park is key to ensuring the long-term survival of São Tomé's most threatened avifauna and native forest ecosystems. Nevertheless, it requires significant investment, given the current staff and logistical limitations of the protected area authority. If São Tomé's tropical forest ecosystems and globally threatened biodiversity are to be protected, particular attention needs to be focused on developing and implementing a rigorous enforcement and surveillance programme, which in turn depends on the identification and development of a sustainable financing approach.

Our work has also shown that even the most threatened species might occur outside the ONP boundaries and use secondary forests. These results are a sign of hope for the future of these species, but should be taken with caution since they represent an improvement on the knowledge about their situation rather than a change in their conservation status. It would be important to better understand the conditions in which they use these areas, to expand suitable habitat through habitat management, control of human activities and expanding the existing network of protected areas in the island. Much of these secondary habitats fall within a proposed buffer zone, which is under threat from large-scale commodity development, while awaiting legal recognition (de Lima et al. 2013b). Improving the protection of key ecosystems outside the only existing protected area and developing an effective management framework for a more sustainable use of resources in edge forest ecosystems is also critical to protect São Tomé's unique biodiversity.

\section{Supplementary Material}

To view supplementary material for this article, please visit https://doi.org/10.1017/ S0959270916000241

\section{Acknowledgements}

We would like to express our gratitude to everyone who contributed to the International Action Plan for the Conservation of Critically Endangered Birds on São Tomé, which was used to guide this work. A special acknowledgment to Eng. Arlindo Carvalho, the General Director for the Environment for supporting our activities in São Tomé. Fieldwork would not have been possible without the help of Silvino Dias, José Malé, Filipe Santiago, Lidiney and countless other Santomeans. A special dedication 
to "Dakubala". We thank António Alberto, Nuno Barros, Mariana Carvalho, Martin Dallimer, Hugulay Maia, Stuart Marsden, Martim Melo, Fábio Olmos and Longtong Turshak for sharing their observations. We also thank the three anonymous reviewers for comments that improved an earlier draft of the manuscript. This work is part of BirdLife's São Tomé and Príncipe Initiative, which was funded by BirdLife's Preventing Extinctions Programme through the Prentice family (as part of BirdLife's Species Champion Programme), the Royal Society for the Protection of Birds, the Disney Worldwide Conservation Fund, the U.S. Fish and Wildlife Service Critically Endangered Animals Conservation Fund (AFR-1411 - F14APoo529), the Mohammed bin Zayed Species Conservation Fund (Project number 13256311) and the Waterbird Society Kushlan Research Grant. R.F.L. was supported by a post-doc grant from the Portuguese Government Foundation for Science and Technology "Fundação para a Ciência e para a Tecnologia" (FCT/MCTES - SFRH/BPD/91494/2012).

\section{References}

Azevedo, F. P. (2015) How many dwarf olive ibises Bostrychia bocagei are there in São Tomé? Use of distance sampling and plot sampling to estimate the population of a critically endangered endemic bird. Msc thesis. Évora University, Portugal.

Barlow, J., Louzada, J., Parry, L., Hernandez, M. I. M., Hawes, J., Peres, C. A., Vaz-deMello, F. Z. and Gardner, T. A. (2010) Improving the design and management of forest strips in human-dominated tropical landscapes: a field test on Amazonian dung beetles. J. Appl. Ecol. 47: 779-788.

Barton, K. (2013) MuMIn: Multi-model inference. R package. Version 1.9.5.

Bolker, B. M., Brooks, M. E., Clark, C. J., Geange, S. W., Poulsen, J. R., Stevens, M. H. H. and White, J. S. S. (2009) Generalized linear mixed models: a practical guide for ecology and evolution. Trends Ecol. Evol. 24: 127-135.

Buchanan, G. M., Donald, P. F. and Butchart, S.H.M. (2011) Identifying priority areas for conservation: a global assessment for forestdependent birds. PLOS ONE 6: e2908o.

Burnham, K. P. and Anderson, D. R. (2002) Model selection and multi-model inference: a practical information-theoretic approach. New York, USA: Springer.

Carvalho, M., Palmeirim, J. M., Rego, F. C., Solé, N., Santana, A. and Fa, J. E. (2015) What motivates hunters to target exotic or endemic species on the island of São Tomé, Gulf of Guinea? Oryx 45: 278-286.

DGA (2006) Lei do Parque Natural do Obô de SãoTomé (Lein.6/2006). São Tomé, SãoTomé e Príncipe: Direcção-Geral do Ambiente, Ministério dos Recursos Naturais e Ambiente.
Diniz, M. A., Fernandes, R., Martins, E. S., Moreira, I. and Paiva, J. (2002) Carta de zonagem agro-ecológica e da vegetação de São Tomé e Príncipe. Garcia da Orta 15: 1-72.

Dutton, J. (1994) Introduced mammals in São Tomé and Príncipe: possible threats to biodiversity. Biodivers. Conserv. 3: 927-938.

Elith, J. and Graham, C. H. (2009) Do they? How do they? WHY do they differ? On finding reasons for differing performances of species distribution models. Ecography 32: 66-77.

Eyzaguirre, P. B. (1986) Small farmers and estates in São Tomé and Príncipe, West Africa. $\mathrm{PhD}$ dissertation. Yale University, USA.

Hijmans, R. and Cameron, S. (2005) Very high resolution interpolated climate surfaces for global land areas. Internatn. J. Climatol. 25: 1965-1978.

Hijmans, R., Phillips, S., Leathwick, J. and Elith, J. (2015) dismo: Species Distribution Modelling. Available at: http://cran.r-project. org $/$ package $=$ dismo.

IUCN (2001) IUCN Red List categories and criteria. Version 3.1. Gland, Switzerland: IUCN.

IUCN (2013) The IUCN Red List of threatened species. Version 2013.1. Available at: http://www.iucnredlist.org.

Jarvis, A., Reuter, H. I., Nelson, A. and Guevara, E. (2008) Hole-filled SRTM for the globe (version 4). Available at: http:// srtm.csi.cgiar.org/.

Jones, P. (1994) Biodiversity in the Gulf of Guinea: an overview. Biodivers. Conserv. $3: 772-784$.

Jones, P. and Tye, A. (2006) The birds of Príncipe, São Tomé and Annobón - an 
annotated checklist. Oxford, UK: British Ornithologists' Union.

Jones, P. J., Burlison, J. P. and Tye, A. (I99I) Conservação dos ecossistemas florestais na República Democrática de São Tomé e Príncipe. Gland, Switzerland: International Union for the Conservation of Nature and Natural Resources.

Kier, G., Kreft, H., Lee, T. M., Jetz, W., Ibisch, P. L., Nowicki, C., Mutke, J. and Barthlott, W. (2009) A global assessment of endemism and species richness across island and mainland regions. Proc. Natl. Ac. Sci. USA 106: 9322-9327.

Le Saout, S., Hoffmann, M., Shi, Y., Hughes, A., Bernard, C., Brooks, T. M., Bertzky, B., Butchart, S. H. M., Stuart, S. N., Badman, T. and Rodrigues, A. S. L. (2013) Protected areas and effective biodiversity conservation. Science 342: 803-805.

Lewis, T. (2015) Habitat associations of the São Tomé fiscal shrike Lanius newtoni. MSc thesis. Nottingham Trent University, UK.

de Lima, R. F. (2012) Land-use management and the conservation of endemic species in the Island of São Tomé. PhD thesis. Lancaster University, UK.

de Lima, R. F., Dallimer, M., Atkinson, P. W. and Barlow, J. (2013a) Biodiversity and landuse change: understanding the complex responses of an endemic-rich bird assemblage. Divers. Distrib. 19: 411-422.

de Lima, R. F., Sampaio, H. and Buchanan, G. (2013b) Survey of critically endangered birds South of the São Tomé Obô Natural Park. Unpublished report. Cambridge, UK: BirdLife International.

de Lima, R. F., Maloney, E., Simison, W. B. and Drewes, R. (2016) Reassessing the conservation status of the shrew Crocidura thomensis, endemic to São Tomé Island. Oryx 50 : 360-363.

Maia, H. A. and Alberto, A. C. (2009) The occurrence of São Tomé short-tail Amaurocichla bocagei in the montane forests of São Tomé. Bull. Brit. Ornithol. Club 129: 213-216.

Maia, H., Gascoigne, A., de Deus, D. and de Lima, R. F. (2014) Notes on the breeding ecology and conservation of the critically endangered dwarf olive ibis Bostrychia bocagei. Bull. Afr. Bird Club 21: 202-205.
Margarido, N. C. I. (2015) Habitat selection by the dwarf olive ibis Bostrychia bocagei, a critically endangered bird endemic to São Tomé Island. Msc thesis. Évora University, Portugal.

Melo, M. (2007) Bird speciation in the Gulf of Guinea island system. PhD thesis. University of Edinburgh, United Kingdom.

Moilanen, A. (2007) Landscape zonation, benefit functions and target-based planning: Unifying reserve selection strategies. Biol. Conserv. 134: 571-579.

Moilanen, A., Franco, A. M. A., Early, R. I., Fox, R., Wintle, B. and Thomas, C. D. (2005) Prioritizing multiple-use landscapes for conservation: methods for large multi-species planning problems. Proc. R. Soc. B - Biol. Sci. 272: 1885-1891.

Monod, T. (1960) Notes botaniques sur les îles de São Tomé et de Príncipe. Bull. de l'Institut Français de l'Afrique Noire 22: 19-80.

Muscarella, R., Galante, P. J., Soley-Guardia, M., Boria, R. A., Kass, J. M., Uriarte, M. and Anderson, R. P. (2014) ENMeval:An R package for conducting spatially independent evaluations and estimating optimal model complexity for Maxent ecological niche models. Methods Ecol. Evol. 5: 1198-1205.

Ndang'ang'a, P. K., Ward-Francis, A., Costa, L., de Lima, R. F., Palmeirim, J., Tavares, J., Buchanan, G., Carvalho, M., Melo, M., Dallimer, M. and Valle, S. (2014) International action plan for the conservation of critically endangered birds on São Tomé: 2014-2018. Cambridge, UK: BirdLife International.

Phillips, S. J. and Dudík, M. (2008) Modelling of species distributions with Maxent: new extensions and a comprehensive evaluation. Ecography 31: 161-175.

R Development Core Team (2015) R: A Language and Environment for Statistical Computing. Available at: http://www.r-project.org.

Salgueiro, A. and Carvalho, S. (2007) Proposta de Plano Nacional de Desenvolvimento Florestal 2003-2005. São Tomé, São Tomé and Príncipe: ECOFAC.

Sampaio, H. A. L, de Lima, R. F., Ward-Francis, A. and Havery, S. J. (2016) Hunters and the critically endangered dwarf olive ibis, endemic to São Tomé. Unpublished report. Cambridge, UK: BirdLife International. 
Silva, H. L. E. (1958) Esboço da carta de aptidão agrícola de São Tomé e Príncipe. Garcia de Orta 6: 61-86.

Solé, N., Alberto, A., Samba, S., Santana, A. and de Lima, R. F. (2012) New hope for the critically endangered São Tomé Grosbeak Neospiza concolor, and an alert to protect Obô Natural Park surroundings. Ostrich 83: 161-164.

Stattersfield, A. J., Crosby, M. J., Long, A. J. and Wege, D. C. (1998) Endemic Bird Areas of the World:Priorities for biodiversity conservation. Cambridge, UK: ICBP.

Tenreiro, F. (1961) A ilha de São Tomé. Lisboa, Portugal: Junta de Investigações Científicas do Ultramar.

Trevino, H. S., Skibial, A. L., Karels, T. J. and Dobson, F. S. (2007) Threats to avifauna on oceanic islands. Conserv. Biol. 21: 125-132.
Visser, H. and De Nijs, T. (2006) The map comparison kit. Environmental Modelling Software 21: 346-358. Available at: http:// www.riks.nl/mck/index.php?page $=$ software.

Warren, D. L. and Seifert, S. N. (2011) Ecological niche modeling in Maxent: The importance of model complexity and the performance of model selection criteria. Ecol. Applic. 21: $335-342$.

Yosef, R. (2008) Family Laniidae (Shrikes). In: J. del Hoyo, A. Elliott and D. A. Christie, eds. Handbook of the birds of the world: Penduline-tits to shrikes. Volume 13. Barcelona, Spain: Lynx Edicions.

Zuur, A. F., Ieno, E. N., Walker, N., Saveliev, A. A. and Smith, G. M. (2009) Mixed effects models and extensions in ecology with $R$. New York, USA: Springer.

\section{RICARDO F. DE LIMA ${ }^{1,2 *}$, JORGE M. PALMEIRIM ${ }^{1}$, GABRIEL CABINDA $^{2}$, RICARDO FONSECA ${ }^{2}$, SEDNEY SAMBA ${ }^{2}$, ARISTIDES SANTANA ${ }^{2}$, GABRIEL OQUIONGO², JOEL OQUIONGO², ESTEVÃO SOARES²,3, LEONEL VIEGAS 2,3 \\ ${ }^{1} C E^{3} C$ - Centre for Ecology, Evolution and Environmental Changes, Faculdade de Ciências, Universidade de Lisboa, Lisbon, Portugal. \\ ${ }^{2}$ Associação Monte Pico, Monte Café, São Tomé, Democratic Republic of São Tomé and Príncipe. \\ 3Parque Natural do Obô de São Tomé, Bom Sucesso, São Tomé, Democratic Republic of São Tomé and Príncipe.}

HUGO SAMPAIO, LUÍS T. COSTA

Sociedade Portuguesa para o Estudo das Aves, Lisbon, Portugal.

JONATHON C. DUNN

School of Biology, Newcastle University, Newcastle upon Tyne, UK.

GRAEME M. BUCHANAN, ALICE WARD-FRANCIS

The Royal Society for the Protection of Birds, Sandy, UK.

*Author for correspondence; e-mail: rfaustinol@gmail.com

Received 20 March 2016; revision accepted 20 June 2016;

Published online 14 November 2016 